\title{
Dose-response effects of a new growth hormone receptor antagonist (B2036-PEG) on circulating, hepatic and renal expression of the growth hormone/insulin-like growth factor system in adult mice
}

\author{
J W van Neck, N F J Dits, V Cingel, I A Hoppenbrouwers, \\ S L S Drop and A Flyvbjerg ${ }^{1}$
}

\author{
Laboratory of Pediatrics, Subdivision of Molecular Endocrinology, Erasmus University/AZR-Sophia, 3015 GD Rotterdam, The Netherlands \\ ${ }^{1}$ Medical Research Laboratories, Institute of Experimental Clinical Research, Aarhus University Hospital, DK-8000 Aarhus C, Denmark \\ (Requests for offprints should be addressed to J W van Neck, Laboratory of Pediatrics, Room Ee1500, Erasmus University Rotterdam, PO Box 1738, \\ 3000 DR Rotterdam, The Netherlands)
}

\begin{abstract}
The effects of growth hormone $(\mathrm{GH})$ in regulating the expression of the hepatic and renal GH and insulin-like growth factor (IGF) system were studied by administering a novel GH receptor antagonist (GHRA) (B2036-PEG) at different doses $(0,1 \cdot 25,2 \cdot 5,5$ and $10 \mathrm{mg} / \mathrm{kg} /$ day $)$ to mice for 7 days. No differences were observed in the groups with respect to body weight, food consumption or blood glucose. However, a dose-dependent decrease was observed in circulating IGF-I levels and in hepatic and renal IGF-I levels at the highest doses. In contrast, in the 5 and $10 \mathrm{mg} / \mathrm{kg} /$ day GHRA groups, circulating and hepatic transcriptional IGF binding protein-3 (IGFBP-3) levels were not modified, likely resulting in a significantly decreased IGF-I/IGFBP-3 ratio. Hepatic GH receptor (GHR) and GH binding protein (GHBP) mRNA levels
\end{abstract}

increased significantly in all GHRA dosage groups. Endogenous circulatory GH levels increased significantly in the 2.5 and $5 \mathrm{mg} / \mathrm{kg} /$ day GHRA groups. Remarkably, increased circulating IGFBP-4 and hepatic IGFBP-4 mRNA levels were observed in all GHRA administration groups. Renal GHR and GHBP mRNA levels were not modified by GHRA administration at the highest doses. Also, renal IGFBP-3 mRNA levels remained unchanged in most GHRA administration groups, whereas IGFBP-1, -4 and -5 mRNA levels were significantly increased in the 5 and $10 \mathrm{mg} / \mathrm{kg} /$ day GHRA administration groups.

In conclusion, the effects of a specific GHR blockade on circulating, hepatic and renal GH/IGF axis reported here, may prove useful in the future clinical use of GHRAs.

Journal of Endocrinology (2000) 167, 295-303

\section{Introduction}

The growth hormone $(\mathrm{GH}) /$ insulin-like growth factor (IGF) axis constitutes a complex system of peptides in the circulation, extracellular space and in most tissues. The classical endocrine effect of pituitary-secreted GH is the induction of IGF-I synthesis in various organs. The liver is believed to be the major source of circulating IGF-I which, in turn, is a negative feedback signal on GH secretion (Namba et al. 1989, Yamasaki et al. 1991).

IGF-I is a member of the IGF system that also consists of IGF-II, two types of IGF receptors and six different IGF binding proteins (IGFBPs) (Kelley et al. 1996). In addition, four IGFBP-related proteins have been described (Baxter et al. 1998).

The GH/IGF axis is important for normal cell growth and differentiation, but has also been shown to be involved in pathophysiological processes. Recently, a series of $\mathrm{GH}$ antagonists has been developed that specifically block the GH receptor (GHRAs) (Chen et al. 1991b, 1994). These GHRAs may be used as intervention in various diseases where GH action is known to play a pathophysiological role (e.g. acromegaly) (Trainer et al. 2000) or is suspected of being involved in organ specific damage (e.g. diabetic kidney disease) (Flyvbjerg et al. 1999a, Segev et al. 1999).

In order to get more detailed information about the effects of specific GH receptor (GHR) blockade on circulating and local components of the GH/IGF axis, a GHRA with an enhanced affinity for the human GHR (B2036-PEG) was studied at different doses in mice. The effects of GHRA administration on the expression of the GH/IGF components were investigated in the liver, thought to be the major regulator of circulating IGFs, and in the kidney, as various kidney diseases may be potential targets for GHRA treatment. 


\section{Materials and Methods}

Animals

Adult female Balb/C(a) mice with initial body weights of $16 \cdot 4 \pm 0 \cdot 2 \mathrm{~g}$ (Bomholtgaard, Ry, Denmark) were used in the study. The animals were housed 7-8 per cage on white special spanwall bedding. They were fed a standard laboratory diet (Altromin No. 1310, Altromin, Lage, Germany), had free access to water and were kept at constant temperature $\left(21 \pm 1{ }^{\circ} \mathrm{C}\right)$, humidity $(55 \pm 5 \%)$ and under a 12-h light, 12-h darkness cycle (lights on from $0700 \mathrm{~h}$ to $1900 \mathrm{~h}$ ). The study complied with Danish regulations for the care and use of laboratory animals.

\section{Study design}

The mice were randomly allocated into five groups of eight animals: (1) animals injected on days $0,2,4$ and 6 with $0.154 \mathrm{~mol} / 1 \mathrm{NaCl}$, the vehicle for the other treatments (control group); (2) animals injected on days $0,2,4$ and 6 with $2.5 \mathrm{mg} / \mathrm{kg}$ human GHR antagonist (GHRA): B2036-PEG (1.25 mg/kg/day GHRA group); (3) animals injected on days $0,2,4$ and 6 with $5 \mathrm{mg} / \mathrm{kg}$ GHRA $(2.5 \mathrm{mg} / \mathrm{kg} /$ day GHRA group); (4) animals injected on days $0,2,4$ and 6 with $10 \mathrm{mg} / \mathrm{kg}$ GHRA $(5 \mathrm{mg} / \mathrm{kg} /$ day GHRA group); (5) animals injected on days $0,2,4$ and 6 with $20 \mathrm{mg} / \mathrm{kg}$ GHRA $(10 \mathrm{mg} / \mathrm{kg} /$ day GHRA group).

Human GHRA (B2036-PEG) was kindly provided by Sensus Drug Development Corporation (Austin, TX, USA) (Fuh et al. 1992). The molecule has a modification in the first GHR binding site resulting in a 30-50 times increased affinity for the human GHR. In addition, in the second GHR binding site, amino acid 120 is modified preventing GHR dimerization (Chen et al. 1991c). GHRA was provided in a pegylated formula to warrant prolonged biological action of the molecule (Clark et al. 1996). The GHRA was dissolved in $0 \cdot 154 \mathrm{~mol} / \mathrm{l} \mathrm{NaCl}$ and injected s.c. on days $0,2,4$, and 6 in an injection volume of $0.5 \mathrm{ml}$. The animals were weighed and their food consumption and blood glucose was determined on days $0,2,4$, and 7 . On day 7, the animals were anesthetized with pentobarbital (50 mg/ $\mathrm{kg}$ i.p.) and non fasting blood samples were collected exactly 5 min later from the retrobulbar plexus through heparinized capillary tubes under light ether anesthesia. The serum samples were kept at $-80{ }^{\circ} \mathrm{C}$ for later analysis. Whole liver and the left kidney were removed and snap frozen in liquid nitrogen.

\section{Blood glucose}

Blood glucose was measured in unanesthetized animals in tail vein blood by Haemoglucotest 1-44 and Reflolux II reflectance meter (Boehringer-Mannheim, Mannheim, Germany).
Serum GH and IGF-I, and hepatic and kidney IGF-I determinations

Serum GH was measured by a radioimmunoassay (RIA) as described previously (Flyvbjerg et al. 1999a). Potential cross-reactivity of the GHRA (B2036-PEG) with the rodent specific GH assay was precluded, as addition in the assay of the GHRA at multiple concentrations (over a range from $0 \cdot 5-5000 \mu \mathrm{g} / \mathrm{l}$ ) did not reveal any significant binding. Serum IGF-I was measured after extraction using acid-ethanol (Flyvbjerg et al. 1999a). The intra-assay and interassay coefficients of variation (CV) were 5\% and 10\% respectively. Tissue extraction of renal and hepatic IGF-I was performed according to D'Ercole et al. (1984) and corrected for the contribution of entrapped serum IGF-I (Flyvbjerg et al. 1992b).

\section{Serum IGFBPs}

SDS-PAGE and Western ligand blotting (WLB) analysis were executed according to the method of Hossenlopp et al. (1986) as described previously (Flyvbjerg et al. 1992a).

Gene expression of GH and IGF system ( $m R N A$ ) in tissues

Gene expression of IGFBP-1 to -6 (mRNA) was measured by Northern blot analysis. Total RNA was extracted from kidney and liver samples by the guanidinium thiocyanate method (Chomczynski \& Sacchi 1987). Glyoxylated-RNA samples were electrophoresed in 1\% agarose gels submerged in $10 \mathrm{mM}$ sodium phosphate $\mathrm{pH}$ $7 \cdot 2$ and transferred to nylon membranes (Hybond $\mathrm{N}^{+}$, Amersham, 's Hertogenbosch, The Netherlands). Filters were hybridized with $1-2 \times 10^{6}$ c.p.m. per ml ${ }^{32}$ P-labeled cDNA fragments encoding for each of the six mouse IGFBPs (Schuller et al. 1994), mouse IGF-I and -II (kindly provided by Dr G I Bell, Howard Hughes Institute, Chicago, IL, USA), rat IGF-I receptor (kindly provided by Dr H Werner and Dr D LeRoith, National Institutes of Health, Bethesda, MD, USA), GHR, GHBP (Mathews et al. 1989) and glyceraldehyde-3-phosphate dehydrogenase (GAPDH) at $65^{\circ} \mathrm{C}$ according to the method of Church \& Gilbert (1984).

\section{Quantification}

Autoradiographs of WLBs were scanned using a laser densitometer (Shimadzu model CS 90001 PC, Shimadzu Europe $\mathrm{GmbH}$, Duisburg, Germany) and the relative densities of the bands expressed in pixels. Northern blots were scanned on a Phosphor Imager (Molecular Dynamics, Sunnyvale, CA, USA) and quantified using ImageQuant software. All measured mRNA results were expressed relative to GAPDH mRNA levels. 


\section{Statistical analysis}

Data were examined for distribution, variance homogeneity (F-test) and analyzed by one-way analysis of variance followed by pair-wise comparisons with the leastsignificant difference method. All data are expressed as means \pm s.E.M., with $n$ indicating the number of mice studied. $P$ values less than 0.05 are considered significant.

\section{Results}

Body weight and organ weights

The body weights of the different study groups at the beginning (day 0) and end (day 7) of the experimental period were determined. The mean body weights on day 0 were $16 \cdot 4 \pm 0 \cdot 2 \mathrm{~g}$ with no differences between the groups. At day 7 , mean body weight increased to $18.9 \pm 0.3 \mathrm{~g}$ in control animals with no differences in the different groups (data not shown). At the end of the experimental period, liver and kidney weights were determined. Liver weight and the weight of the kidneys in the control group were $926 \pm 35 \mathrm{mg}$ and $237 \pm 3 \mathrm{mg}$ respectively. The GHRA administration regimen demonstrated no significant effects on the weight of liver or kidneys (data not shown).

\section{Food consumption and blood glucose}

Food consumption over $24 \mathrm{~h}$ was measured during the study period on a group basis. Mean food intake per mouse of the control group was $4 \cdot 2 \pm 0 \cdot 1 \mathrm{~g}$ per $24 \mathrm{~h}$. Food consumption did not differ significantly during the experimental period in any of the groups (data not shown). Blood glucose values were measured in all animals at the end of the experimental period and did not change significantly in any of the experimental groups (data not shown).

\section{Serum IGF-I and GH}

At the end of the study period serum IGF-I levels were determined in all groups (Fig. 1A). Compared with placebo control levels, in the $1.25 \mathrm{mg}$ GHRA group serum IGF-I levels were unchanged, whereas in the $2 \cdot 5,5$ and $10 \mathrm{mg}$ GHRA groups serum IGF-I levels were reduced to $75 \%(P=0.006), 70 \%(P=0 \cdot 001)$ and $51 \%$ $(P<0 \cdot 001)$ of control values respectively (Fig. 1A). Compared with the other groups significant and dosedependent decreases in circulatory IGF-I levels were observed (1.25 mg versus $2.5 \mathrm{mg}$ GHRA group, $P<0 \cdot 008$; $5 \mathrm{mg}$ versus $10 \mathrm{mg}$ GHRA group, $P=0 \cdot 011)$. Figure $1 \mathrm{~B}$ shows serum $\mathrm{GH}$ levels in the five experimental groups by the end of the study (day 7). It has been demonstrated previously that barbital anesthesia induces a marked rise in GH levels that lasts for up to $90 \mathrm{~min}$ (Takahashi et al. 1971). Therefore, the endogenous GH levels given in Fig. $1 \mathrm{~B}$ are stimulated values. Increased serum $\mathrm{GH}$ levels amounting to $183 \%(P=0 \cdot 003)$ and $145 \%(P=0 \cdot 01)$ of control values were seen in the $2.5 \mathrm{mg}$ GHRA and $5 \mathrm{mg}$ GHRA groups respectively.

\section{Serum IGFBPs}

Using WLB, four distinct bands were obtained. A double band at $38-42 \mathrm{kDa}$ representing IGFBP-3, a single $30 \mathrm{kDa}$ band (IGFBP-1 and -2) and a $24 \mathrm{kDa}$ band identified as IGFBP-4.

GHRA administration did not affect IGFBP-3 levels with the exception of the group receiving $2.5 \mathrm{mg}$ GHRA. In this group IGFBP-3 levels were significantly decreased to $78 \%$ of control levels $(P=0 \cdot 04)$ (Fig. 1C). Circulatory $30 \mathrm{kDa}$ (IGFBP-1 and -2) levels were unchanged in all groups (Fig. 1C). IGFBP-4 levels were significantly increased in the $1 \cdot 25,2.5$ and $5 \mathrm{mg}$ GHRA groups to $143 \%(P=0 \cdot 008), 142 \%(P=0 \cdot 04)$ and $159 \%(P=0 \cdot 001)$ of control levels. In the $10 \mathrm{mg}$ GHRA group, IGFBP-4 levels were near significantly increased to $125 \%(P=0 \cdot 06)$ of control levels (Fig. 1C). In the 5 and $10 \mathrm{mg}$ GHRA groups the calculated ratio of IGF-I to IGFBP-3 was significantly decreased to $71 \%(P=0.001)$ and $53 \%$ $(P<0 \cdot 001)$ of control values.

\section{Hepatic GH/IGF system expression}

GHRA administration for 7 days significantly increased hepatic GHR mRNA expression at all doses tested (Fig. 2B). GHBP mRNA expression was dosedependently increased in the $1.25 \mathrm{mg}, 2.5 \mathrm{mg}$ and $5 \mathrm{mg}$ GHRA groups (control versus $1.25 \mathrm{mg}$ GHRA group, $P<0.001 ; 1.25 \mathrm{mg}$ versus $2.5 \mathrm{mg}$ GHRA group, $P<0 \cdot 001 ; 2 \cdot 5 \mathrm{mg}$ versus $5 \mathrm{mg}$ GHRA group, $P=0 \cdot 044)$. A representative Northern blot is given in Fig. 2A.

Hepatic IGF-I protein levels, however, demonstrated a tendency to decline in all GHRA administration groups, only reaching significance in the $10 \mathrm{mg}$ GHRA group $(P=0.004)$ (see Fig. 4A). Hepatic IGF-I mRNA levels (predominantly $1.2 \mathrm{~kb}$ and $7 \mathrm{~kb}$ ) also had a tendency to decline in all GHRA administration groups reaching significance in the $2.5 \mathrm{mg}$ GHRA $(P=0.01)$ and $10 \mathrm{mg}$ GHRA $(P=0 \cdot 05)$ groups (Fig. 2C).

Compared with control animals, hepatic IGFBP-1 mRNA levels had a tendency to increase, only reaching significance in the $2.5 \mathrm{mg}$ GHRA group $(P<0.03)$ (Fig. 2D). Hepatic IGFBP-2 mRNA levels were significantly decreased in the $1 \cdot 25,2 \cdot 5$ and $5 \mathrm{mg}$ GHRA groups $(P<0.001, P=0.002$ and $P=0.001$ respectively) (Fig. 2D). IGFBP-3 mRNA levels were unchanged during GHRA administration, whereas IGFBP-4 mRNA levels were significantly increased in all GHRA administration groups (Fig. 2D). Hepatic IGFBP-5 and -6, IGF-II and IGF-I receptor mRNA levels were not detectable in any of the groups. 

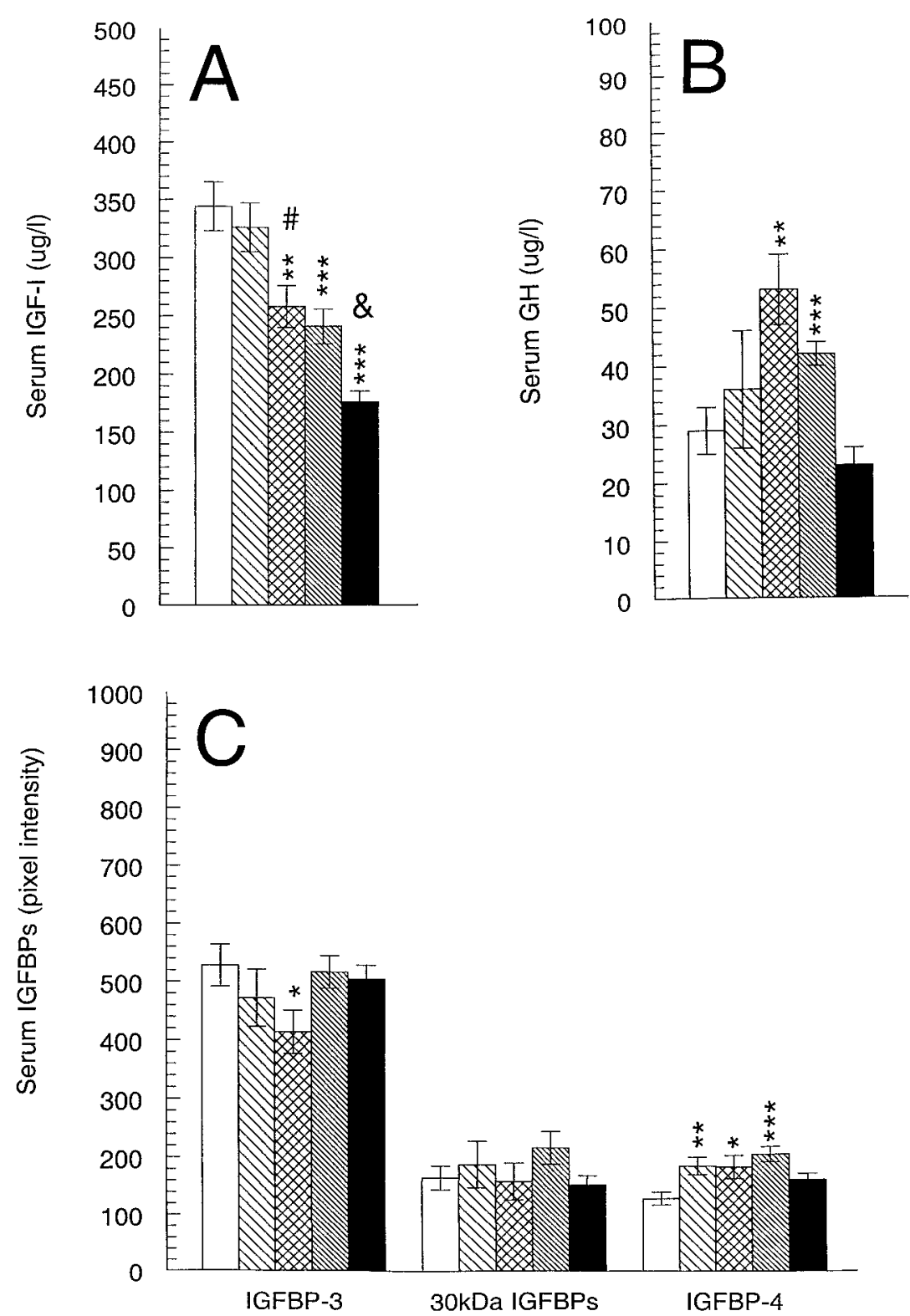

Figure 1 Circulatory levels of (A) IGF-I, (B) GH, and (C) IGFBP in adult mice injected for 7 days with placebo (open bars), $1.25 \mathrm{mg} / \mathrm{kg}$ /day (broad-hatched bars), $2.5 \mathrm{mg} / \mathrm{kg} /$ day (cross-hatched bars), $5 \mathrm{mg} / \mathrm{kg} /$ day (narrow-hatched bars) and $10 \mathrm{mg} / \mathrm{kg} /$ day (solid bars) GHRA B2036-PEG. Values are means \pm S.E.M. $(n=8) .{ }^{*} P=0 \cdot 04,{ }^{* *} P<0 \cdot 01,{ }^{*} * * \leq 0 \cdot 001$, statistical significance level between the indicated GHRA group and the placebo control. ${ }^{\#} P=0.008$ significance level between the $1.25 \mathrm{mg}$ and the $2.5 \mathrm{mg}$ GHRA group; ${ }^{\&} P=0.011$ significance level between the $5 \mathrm{mg}$ and $10 \mathrm{mg}$ GHRA group.

\section{Renal GH/IGF system expression}

GHRA administration did not modify renal GHR mRNA levels except for the $1.25 \mathrm{mg}$ GHRA group where a significantly decreased GHR mRNA level was observed $(P=0.03)$ (Fig. 3B). A representative Northern blot is given in Fig. 3A.
GHRA administration also did not modify renal GHBP mRNA levels in most of the groups. Only the $10 \mathrm{mg}$ GHRA group demonstrated a significantly increased GHBP level $(P=0 \cdot 005)$ (Fig. 3B).

Compared with the placebo control, in the 5 and $10 \mathrm{mg}$ GHRA groups renal IGF-I protein levels significantly 
A

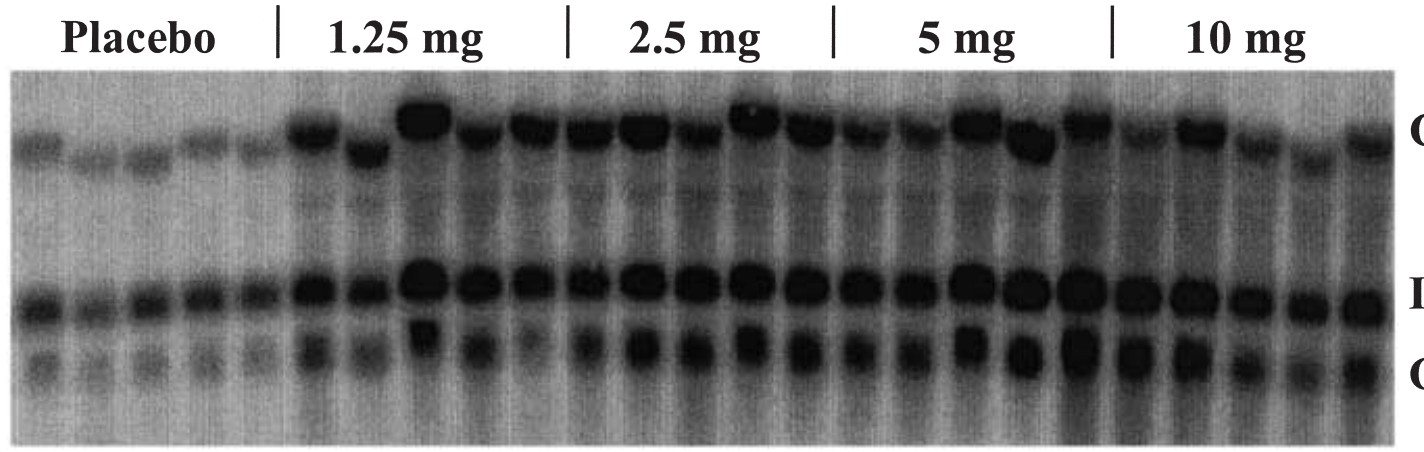

\section{GHR}

IGFBP-4

GHBP

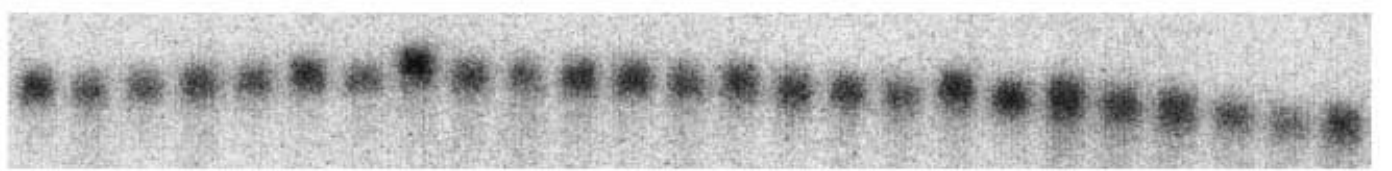

\section{GAPDH}
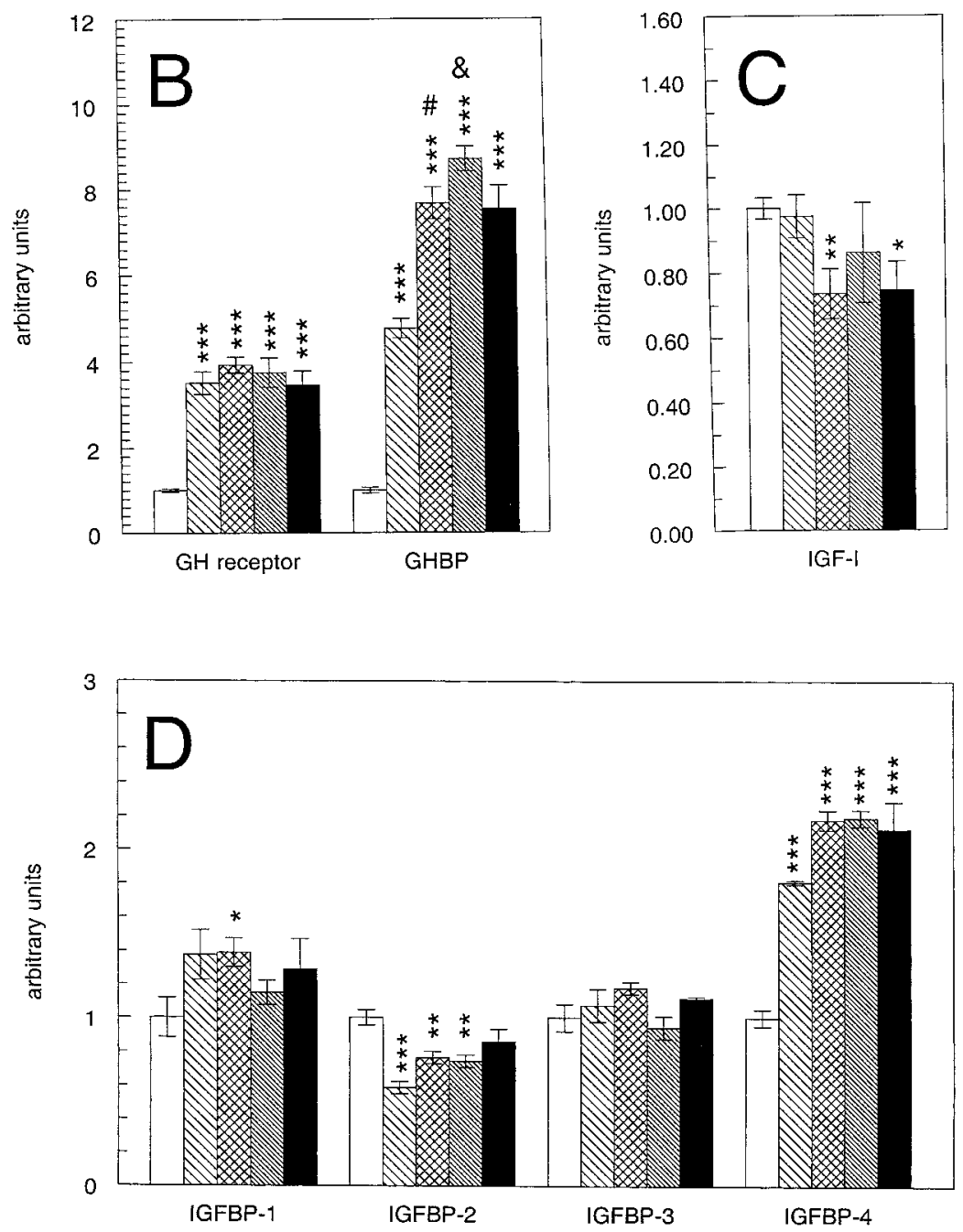

Figure 2 (A) Representative mRNA expression pattern of GHR, GHBP, IGFBP-4 and GAPDH in livers of adult mice injected for 7 days with placebo, $1 \cdot 25,2 \cdot 5,5$ and $10 \mathrm{mg} / \mathrm{kg} /$ day GHRA B2036-PEG. (B-D) Relative hybridization of (B) GHR, GHBP mRNA, (C) IGF-I mRNA, and (D) IGFBP-1, - 2, -3, -4 mRNA in liver of adult mice injected for 7 days with placebo (open bars), $1.25 \mathrm{mg} / \mathrm{kg} /$ day (broad-hatched bars), $2.5 \mathrm{mg} / \mathrm{kg} /$ day (cross-hatched bars), $5 \mathrm{mg} / \mathrm{kg} /$ day (narrow-hatched bars) and $10 \mathrm{mg} / \mathrm{kg} /$ day (solid bars) GHRA B2036-PEG. Values are based on quantitations of Northern blots, compensated for RNA loading differences. Values are represented as means \pm S.E.M. $(n=8)$ and expressed relative to the placebo control. ${ }^{*} P \leq 0 \cdot 05,{ }^{* *} P \leq 0 \cdot 01,{ }^{* * *} P \leq 0 \cdot 001$, statistical significance level between the indicated GHRA group and the placebo control. ${ }^{\#} P<0 \cdot 001$ significance level between the $1.25 \mathrm{mg}$ and the $2.5 \mathrm{mg}$ GHRA group; ${ }^{\&} P=0.044$ significance level between the $2.5 \mathrm{mg}$ and $5 \mathrm{mg}$ GHRA group. 
A
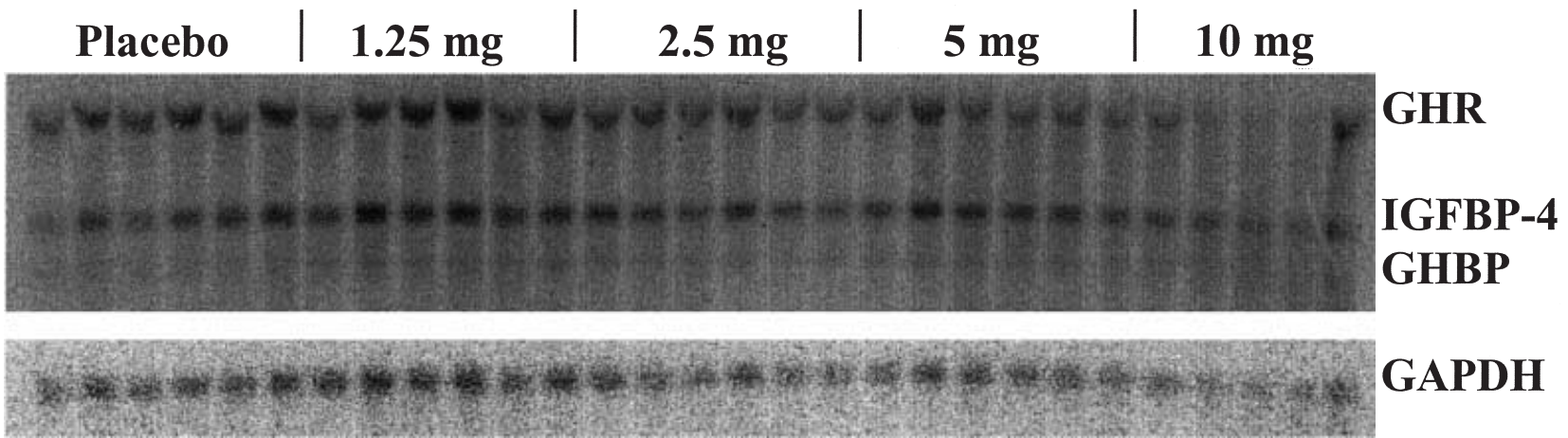

GAPDH
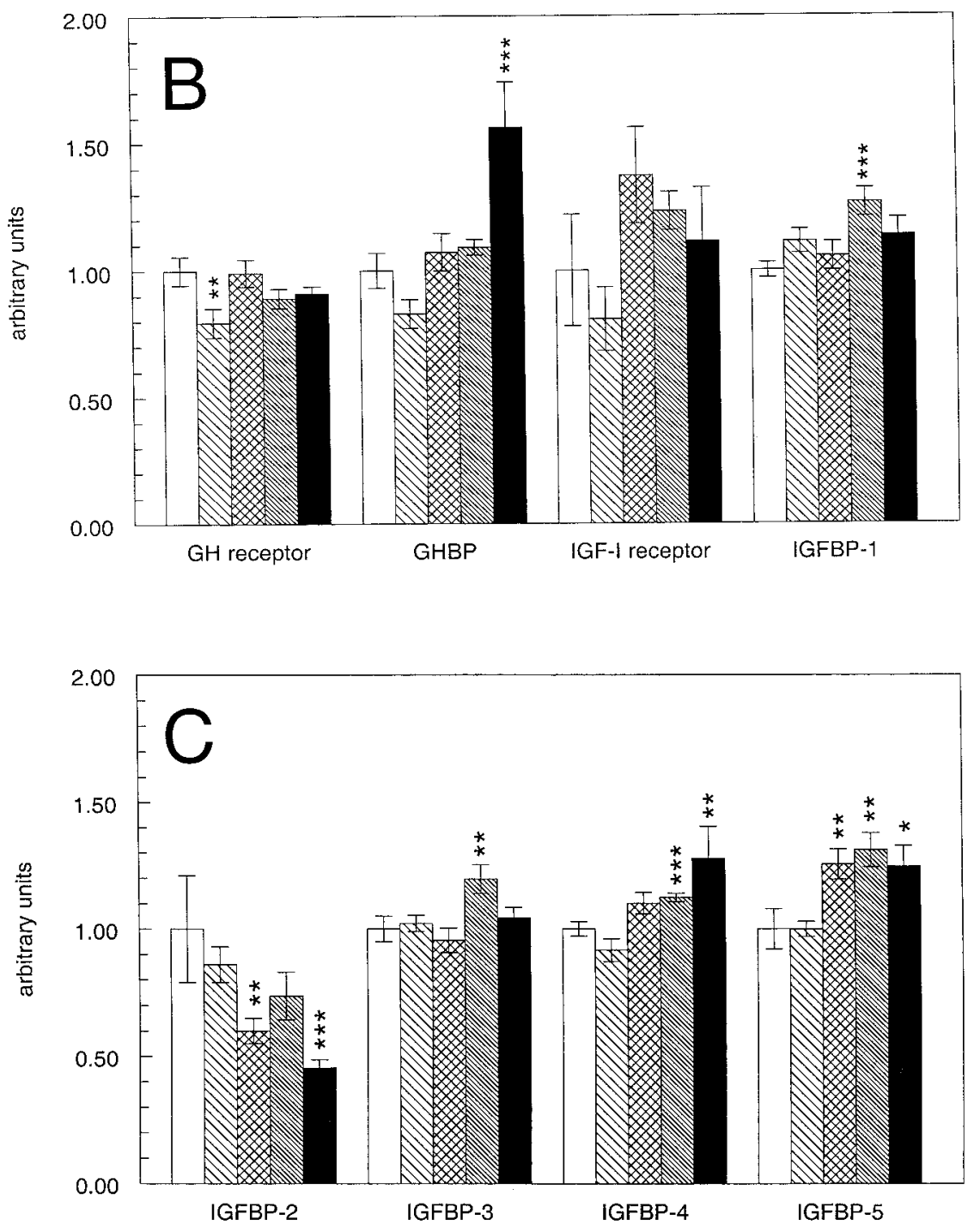

Figure 3 (A) Representative mRNA expression pattern of GHR, GHBP, IGFBP-4 and GAPDH in kidneys of adult mice injected for 7 days with placebo, $1 \cdot 25,2 \cdot 5,5$ and $10 \mathrm{mg} / \mathrm{kg} /$ day GHRA B2036-PEG. (B and C) Relative hybridization of (B) $\mathrm{GH}$ receptor, GHBP, IGF-I receptor and IGFBP-1 mRNA and (C) IGFBP- $2,-3,-4$ and -5 mRNA in kidneys of adult mice injected for 7 days with placebo (open bars),

$1.25 \mathrm{mg} / \mathrm{kg} /$ day (broad-hatched bars), $2.5 \mathrm{mg} / \mathrm{kg} /$ day (cross-hatched bars), $5 \mathrm{mg} / \mathrm{kg} /$ day (narrow-hatched bars) and $10 \mathrm{mg} / \mathrm{kg} /$ day (solid bars) GHRA B2036-PEG. Values are based on quantitations of Northern blots, compensated for RNA loading differences. Values are represented as means \pm S.E.M. $(n=8)$ and expressed relative to the placebo control. ${ }^{\star} P=0.05$, ${ }^{* *} P \leq 0 \cdot 03,{ }^{* * *} P \leq 0 \cdot 005$, statistical significance level between the indicated GHRA group and the placebo control. 


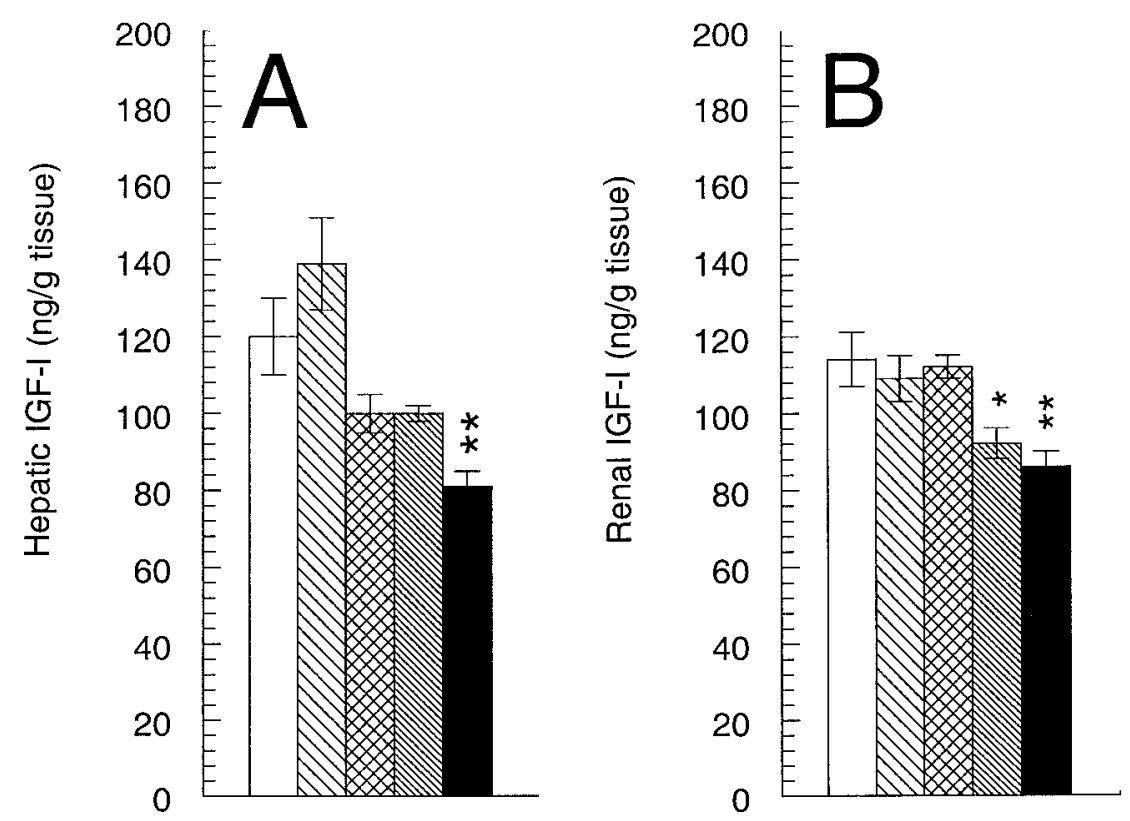

Figure 4 (A) Hepatic and (B) renal IGF-I protein levels in adult mice injected for 7 days with placebo (open bars), $1.25 \mathrm{mg} / \mathrm{kg} /$ day (broad-hatched bars), $2.5 \mathrm{mg} / \mathrm{kg} /$ day (cross-hatched bars), $5 \mathrm{mg} / \mathrm{kg} /$ day (narrow-hatched bars) and $10 \mathrm{mg} / \mathrm{kg} /$ day (solid bars) GHRA B2036-PEG. Values are means \pm S.E.M. $(n=8) .{ }^{*} P=0 \cdot 02,{ }^{*} P \leq 0 \cdot 005$, statistical significance level between the indicated GHRA group and the placebo control.

decreased $(P=0.02$ and $P=0.005$ respectively) (Fig. 4B). IGFBP-1 and -3 mRNA levels were not modified by GHRA administration except for the $5 \mathrm{mg}$ GHRA administration group where a significant increase was observed ( $P=0.03$ and $P=0.005$ respectively) (Fig. 3C). IGFBP-2 mRNA levels decreased dose-dependently with increasing GHRA concentrations which, however, only reached significance in the 2.5 and $10 \mathrm{mg}$ GHRA groups $(P=0.03$ and $P=0.005$ respectively) (Fig. 3C). IGFBP-4 mRNA levels significantly increased in the 5 and $10 \mathrm{mg}$ GHRA groups $(P=0.004$ and $P=0.03$ respectively) and IGFBP-5 mRNA levels significantly increased in the $2 \cdot 5$, 5 and $10 \mathrm{mg}$ GHRA groups $(P=0.03, P=0.01$ and $P=0.05$ respectively) (Fig. 3C). Renal IGF-I receptor expression did not significantly change with any of the treatments. Renal IGF-I, IGF-II and IGFBP-6 mRNA levels were not detectable in any of the groups.

\section{Discussion}

In the present study, for the first time, the specific blockage of $\mathrm{GH}$ at the organ level was studied using a novel GHRA (B2036-PEG). B2036-PEG is a member of a GHRA family recently developed for the human GHR that retained its activity in mice. Studies using GHRAs in vitro demonstrated high affinity binding to the GH receptor (Chen et al. 1991b,c, Fuh et al. 1992). Transgenic animals expressing GHRAs phenotypically resembled dwarf animals with reduced circulating IGF-I levels (Chen et al. 1990, 1991a). When GHRA transgenic animals were made diabetic, protection to GH- and IGF-I-induced renal damage was observed (Chen et al. 1995, 1996). Furthermore, GHRA treatment protected diabetic mice from renal damage (Flyvbjerg et al. 1999a, Segev et al. 1999) and abolished compensatory renal growth in uninephrectomized mice (Flyvbjerg et al. 1999b).

To elucidate further the effects of GHRA, the present study was performed with exogenous administration of a long-acting formula of GHRA at increasing doses in adult animals. The effects on body weight and on the circulating, hepatic and renal GH and IGF systems were analyzed.

In our study, increasing GHRA doses proportionally decreased circulating and hepatic IGF-I levels. In contrast, circulatory IGFBP-3 levels remained constant. The IGF-I and IGFBP-3 serum values matched hepatic mRNA levels as a dose-dependent decrease in hepatic IGF-I mRNA values was observed, whereas the IGFBP-3 mRNA levels were unchanged at any of the GHRA doses used. In the circulation, this might indicate a decrease in IGF-I bioavailability. In rodents, there is evidence that serum IGFBP-3 is regulated directly by IGF-I and is independent of GH (Clemmons et al. 1989, CamachoHubner et al. 1991). However, in our study circulatory IGFBP-3 protein and hepatic IGFBP-3 mRNA levels remained unchanged despite increased $\mathrm{GH}$ and decreased 
IGF-I levels. The latter finding is in contrast to the human, where serum IGFBP-3 levels directly reflected GH levels (Blum et al. 1993). In addition, patients lacking a functional GHR demonstrated high serum GH and low serum IGF-I and IGFBP-3 levels (Cotterill et al. 1992, Gargosky et al. 1993). The reasons for these differences in serum IGFBP-3 regulation are unclear.

GHRA administration significantly increased circulatory GH levels, although at the highest GHRA concentration, GH levels were decreased to control values. We cannot readily explain this latter observation. As expected, the increased blocking of the GHRs was reflected by a dose-dependent decrease in circulatory IGF-I levels. Therefore, a dose-dependent increase in circulating GH levels was expected. It could be argued that, due to cross-reactivity of the GHRA and GH, the GHRA interfered in our GH assay. However, this possibility had to be excluded as we could not demonstrate any crossreactivity between the human GHRA and the mouse GH in the rodent specific RIA used for the measurements of circulatory GH levels. Furthermore, one could argue that a single $\mathrm{GH}$ determination is not the best estimate of $\mathrm{GH}$ secretion. However, as shown before, a single barbitalstimulated GH measurement may be used as an estimate of GH levels (Takahashi et al. 1971).

GHRA administration significantly increased hepatic GHR and GHBP mRNA levels, whereas renal GHR and GHBP mRNA levels did not change significantly. These results are in agreement with other studies examining renal GHR/GHBP mRNA levels (Chen et al. 1997, Flyvbjerg et al. 1999b, Segev et al. 1999). Our study may represent a compensatory upregulation of the GHR gene expression in response to the functional blockade of the GHR by the GHRA. However, in contrast to our findings, Chen et al. (1997) using GHRA expressing transgenic mice did not observe increased hepatic GHR/GHBP mRNA expression although strongly enhanced liver GHR and serum GHBP protein levels were found in these same GHRA transgenic animals (Chen et al. 1997, Sotelo et al. 1998).

In GH-deficient dwarf rats, decreased renal IGF-I mRNA and increased renal IGFBP-1 mRNA levels were demonstrated that were normalized with exogenous $\mathrm{GH}$ administration (Kobayashi et al. 1995). In our study, increased GHRA doses did not have an effect on circulatory $30 \mathrm{kDa}$ IGFBPs or hepatic and renal IGFBP-1 mRNA levels. Remarkably, GHRA administration did increase circulatory IGFBP-4 protein, hepatic IGFBP-4 mRNA and, at higher doses, renal IGFBP-4 mRNA levels also. This stimulation of IGFBP-4 expression, in addition to the decrease in the IGF-I/IGFBP-3 ratio, may lead to a further reduction in IGF-I bioavailability in GHRA-treated animals. Kobayashi et al. (1995) also demonstrated increased IGFBP-4 mRNA levels in dwarf rats that, however, were not influenced by GH administration. Therefore, multiple mechanisms may be operative in regulating the expression of this gene.
In summary, in this study we demonstrated that administration of a specific GHRA dose-dependently decreased hepatic and serum IGF-I with no effect on the expression of hepatic or renal IGFBP-1 and -3 levels, while stimulating hepatic and circulatory IGFBP-4 levels, likely creating a significant decrease in IGF-I bioavailability. Our findings provide a framework for understanding the usefulness of GHRA as a therapeutic drug. GHRA treatment may be beneficial in inhibiting the GH/IGF-I axis in diseases in which its involvement is implicated, such as acromegaly and GH/IGF-I sensitive tumors. Furthermore, GHRA administration may influence organ specific, direct, $\mathrm{GH}$ action in conditions characterized by renal damage such as diabetic nephropathy.

\section{Acknowledgements}

We thank Karen Mathiassen, Kirsten Nyborg and Ninna Rosenqvist for excellent technical assistance. Bram van der Eerden, Department of Pediatrics, University of Leiden, The Netherlands is thanked for the GHR and GHBP cDNA constructs. This work was supported by grants from the Sophia Foundation for Medical Research, the Dutch Diabetes Association, Novo-Nordisk Insulin Laboratories, the Danish Diabetes Association, the Danish Kidney Foundation, the Danish Medical Research Council (\#9700592), the Novo Foundation, the Nordic Insulin Foundation, the Eva and Henry Fraenkels Memorial Foundation, the Aage Louis-Hansen Memorial Foundation and the Aarhus University/Novo Nordisk Center for Research in Growth and Regeneration (\#9600822). The GHRA (B2036-PEG) was a generous gift from the Sensus Drug Development Corporation, Austin, Texas, USA.

\section{References}

Baxter RC, Binoux MA, Clemmons DR, Conover CA, Drop SL, Holly JM, Mohan S, Oh Y \& Rosenfeld RG 1998

Recommendations for nomenclature of the insulin-like growth factor binding protein superfamily. Endocrinology 1394036.

Blum WF, Albertsson-Wikland K, Rosberg S \& Ranke MB 1993 Serum levels of insulin-like growth factor-I (IGF-I) and IGF binding protein-3 reflect spontaneous growth hormone secretion. Journal of Clinical Endocrinology and Metabolism 76 1610-1616.

Camacho-Hubner C, Clemmons DR \& D’Ercole AJ 1991 Regulation of insulin-like growth factor (IGF) binding proteins in transgenic mice with altered expression of growth hormone and IGF-I. Endocrinology 129 1201-1206.

Chen NY, Chen WY, Bellush L, Yang CW, Striker LJ, Striker GE \& Kopchick JJ 1995 Effects of streptozotocin treatment in growth hormone $(\mathrm{GH})$ and $\mathrm{GH}$ antagonist transgenic mice. Endocrinology 136 660-667.

Chen NY, Chen WY \& Kopchick JJ 1996 A growth hormone antagonist protects mice against streptozotocin induced glomerulosclerosis even in the presence of elevated levels of glucose and glycated hemoglobin. Endocrinology 137 5163-5165. 
Chen NY, Chen WY \& Kopchick JJ 1997 Liver and kidney growth hormone $(\mathrm{GH})$ receptors are regulated differently in diabetic $\mathrm{GH}$ and GH antagonist transgenic mice. Endocrinology 138 1988-1994.

Chen WY, Wight DC, Wagner TE \& Kopchick JJ 1990 Expression of a mutated bovine growth hormone gene suppresses growth of transgenic mice. PNAS 87 5061-5065.

Chen WY, White ME, Wagner TE \& Kopchick JJ 1991 a Functional antagonism between endogenous mouse growth hormone $(\mathrm{GH})$ and a $\mathrm{GH}$ analog results in dwarf transgenic mice. Endocrinology 129 1402-1408.

Chen WY, Wight DC, Chen NY, Coleman TA, Wagner TE \& Kopchick JJ $1991 b$ Mutations in the third alpha-helix of bovine growth hormone dramatically affect its intracellular distribution in vitro and growth enhancement in transgenic mice. Journal of Biological Chemistry 266 2252-2258.

Chen WY, Wight DC, Mehta BV, Wagner TE \& Kopchick JJ 1991 c Glycine 119 of bovine growth hormone is critical for growthpromoting activity. Molecular Endocrinology 5 1845-1852.

Chen WY, Chen N, Yun J, Wagner TE \& Kopchick JJ 1994 in vitro and in vivo studies of the antagonistic effects of human growth hormone analogs. Journal of Biological Chemistry 269 15892-15897.

Chomczynski P \& Sacchi N 1987 Single-step method of RNA isolation by acid guanidinium thiocyanate-phenol-chloroform extraction. Analytical Biochemistry 162 156-159.

Church GM \& Gilbert W 1984 Genomic sequencing. PNAS 81 1991-1995.

Clark R, Olson K, Fuh G, Marian M, Mortensen D, Teshima G, Chang S, Chu H, Mukku V, Canova-Davis E, Somers T, Cronin M, Winkler M \& Wells JA 1996 Long-acting growth hormones produced by conjugation with polyethylene glycol. Journal of Biological Chemistry 271 21969-21977.

Clemmons DR, Thissen JP, Maes M, Ketelslegers JM \& Underwood LE 1989 Insulin-like growth factor-I (IGF-I) infusion into hypophysectomized or protein-deprived rats induces specific IGFbinding proteins in serum. Endocrinology 125 2967-2972.

Cotterill AM, Holly JM, Taylor AM, Davies SC, Coulson VJ, Preece MA, Wass JA \& Savage MO 1992 The insulin-like growth factor (IGF)-binding proteins and IGF bioactivity in Laron-type dwarfism. Journal of Clinical Endocrinology and Metabolism 74 56-63.

D’Ercole AJ, Stiles AD \& Underwood LE 1984 Tissue concentrations of somatomedin C: further evidence for multiple sites of synthesis and paracrine or autocrine mechanisms of action. PNAS $\mathbf{8 1}$ 935-939.

Flyvbjerg A, Kessler U, Dorka B, Funk B, Orskov H \& Kiess W 1992a Transient increase in renal insulin-like growth factor binding proteins during initial kidney hypertrophy in experimental diabetes in rats. Diabetologia 35 589-593.

Flyvbjerg A, Marshall SM, Frystyk J, Hansen KW, Harris AG \& Orskov H $1992 b$ Octreotide administration in diabetic rats: effects on renal hypertrophy and urinary albumin excretion. Kidney International 41 805-812.

Flyvbjerg A, Bennett WF, Rasch R, Kopchick JJ \& Scarlett JA 1999a Inhibitory effect of a growth hormone receptor antagonist (G120KPEG) on renal enlargement, glomerular hypertrophy, and urinary albumin excretion in experimental diabetes in mice. Diabetes $\mathbf{4 8}$ 377-382.

Flyvbjerg A, Bennett WF, Rasch R, van Neck JW, Groffen CA, Kopchick JJ \& Scarlett JA 1999 b Compensatory renal growth in uninephrectomized adult mice is growth hormone dependent. Kidney International 56 2048-2054.

Fuh G, Cunningham BC, Fukunaga R, Nagata S, Goeddel DV \& Wells JA 1992 Rational design of potent antagonists to the human growth hormone receptor. Science 256 1677-1680.

Gargosky SE, Wilson KF, Fielder PJ, Vaccarello MA, Guevara-Aguirre J, Diamond FB, Baxter RC, Rosenbloom AL \& Rosenfeld RG 1993 The composition and distribution of insulin-like growth factors (IGFs) and IGF-binding proteins (IGFBPs) in the serum of growth hormone receptor-deficient patients: effects of IGF-I therapy on IGFBP-3. Journal of Clinical Endocrinology and Metabolism 77 1683-1689.

Hossenlopp P, Seurin D, Segovia-Quinson B, Hardouin S \& Binoux M 1986 Analysis of serum insulin-like growth factor binding proteins using western blotting: use of the method for titration of the binding proteins and competitive binding studies. Analytical Biochemistry 154 138-143.

Kelley KM, Oh Y, Gargosky SE, Gucev Z, Matsumoto T, Hwa V, Ng L, Simpson DM \& Rosenfeld RG 1996 Insulin-like growth factor-binding proteins (IGFBPs) and their regulatory dynamics. International Journal of Biochemistry Cell Biology 28 619-637.

Kobayashi S, Nogami H \& Ikeda T 1995 Growth hormone and nutrition interact to regulate expressions of kidney IGF-I and IGFBP mRNAs. Kidney International 48 65-71.

Mathews LS, Enberg B \& Norstedt G 1989 Regulation of rat growth hormone receptor gene expression. Journal of Biological Chemistry 264 9905-9910.

Namba H, Morita S \& Melmed S 1989 Insulin-like growth factor-I action on growth hormone secretion and messenger ribonucleic acid levels: interaction with somatostatin. Endocrinology 124 1794-1799.

Schuller AG, Groffen C, van Neck JW, Zwarthoff EC \& Drop SL 1994 cDNA cloning and mRNA expression of the six mouse insulin-like growth factor binding proteins. Molecular and Cellular Endocrinology 104 57-66.

Segev Y, Landau D, Rasch R, Flyvbjerg A \& Phillip M 1999 Growth hormone receptor antagonism prevents early renal changes in nonobese diabetic mice. Journal of the American Society for Nephrology 10 2374-2381.

Sotelo AI, Bartke A, Kopchick JJ, Knapp JR \& Turyn D 1998 Growth hormone $(\mathrm{GH})$ receptors, binding proteins and IGF-I concentrations in the serum of transgenic mice expressing bovine GH agonist or antagonist. Journal of Endocrinology 158 53-59.

Takahashi K, Daughaday WH \& Kipnis DM 1971 Regulation of immunoreactive growth hormone secretion in male rats. Endocrinology 88 909-917.

Trainer PJ, Drake WM, Katznelson L, Freda PU, Herman-Bonert V, van der Lely AJ, Dimaraki EV, Stewart PM, Friend KE, Vance ML et al. 2000 Treatment of acromegaly with the growth hormonereceptor antagonist pegvisomant. New England Journal of Medicine 342 1171-1177.

Yamasaki H, Prager D, Gebremedhin S, Moise L \& Melmed S 1991 Binding and action of insulin-like growth factor-I in pituitary tumor cells. Endocrinology 128 857-862.

Received 10 April 2000

Accepted 28 June 2000 